University of Nebraska - Lincoln

DigitalCommons@University of Nebraska - Lincoln

USDA National Wildlife Research Center - Staff

Publications

U.S. Department of Agriculture: Animal and Plant Health Inspection Service

2009

\title{
Longevity of Dayglo Fluorescent Particle Marker Used to Mark Birds in Flight Pen and Field
}

Shelagh K. Tupper

John L. Cummings

Richard M. Engeman

USDA-APHIS-Wildlife Services, s_r100@yahoo.com

Follow this and additional works at: https://digitalcommons.unl.edu/icwdm_usdanwrc

Part of the Environmental Sciences Commons

Tupper, Shelagh K.; Cummings, John L.; and Engeman, Richard M., "Longevity of Dayglo Fluorescent Particle Marker Used to Mark Birds in Flight Pen and Field" (2009). USDA National Wildlife Research Center - Staff Publications. 974.

https://digitalcommons.unl.edu/icwdm_usdanwrc/974

This Article is brought to you for free and open access by the U.S. Department of Agriculture: Animal and Plant Health Inspection Service at DigitalCommons@University of Nebraska - Lincoln. It has been accepted for inclusion in USDA National Wildlife Research Center - Staff Publications by an authorized administrator of DigitalCommons@University of Nebraska - Lincoln. 


\title{
Longevity of DayGlo fluorescent particle marker used to mark birds in flight pen and field
}

\author{
Shelagh K. Tupper ${ }^{\mathrm{A}, \mathrm{B}}$, John L. Cummings ${ }^{\mathrm{A}}$ and Richard M. Engeman ${ }^{\mathrm{A}}$ \\ A United States Department of Agriculture, Animal Plant Health Inspection Service, Wildlife Services, \\ National Wildlife Research Center, 4101 West LaPorte Avenue, Fort Collins, CO 80521, USA. \\ ${ }^{\mathrm{B} C}$ Corresponding author. Email: shelagh.k.tupper@aphis.usda.gov
}

\begin{abstract}
Spray application of fluorescent particles is a widely used and very valuable technique for marking birds. This remains one of the few practical means to mark large numbers of birds for monitoring movement, despite recent availability of a variety of more technologically advanced options. We monitored the longevity of the DayGlo fluorescent particle marker on red-winged blackbirds under simulated field conditions in a flight pen, and in an observational field experiment. In the pen study we banded 52 red-winged blackbirds with individually numbered leg bands, and sprayed them with DayGlo fluorescent particle marker from a distance of $\sim 50 \mathrm{~cm}$, on 1 December 2004 . These birds were recaptured and DayGlo fluorescent particle marks assessed 11 times until 10 August 2005. All 31 surviving birds at the conclusion of the study (i.e. after 254 days) retained at least some DayGlo fluorescent particle marker on one or more body regions. Wings retained DayGlo fluorescent particle marks longer than other body regions and thus could be used to identify marks in largescale collections. Roosting wild blackbirds aerially marked in September and October 2005 retained marks through June 2006, 263 days after marking. The formulation used is inexpensive (US\$4.00 L $\mathrm{L}^{-1}$ ), easy-to-apply at many scales and practical for many species (e.g. starlings, blackbirds, sparrows, gulls and shorebirds).
\end{abstract}

\section{Introduction}

Several external marking techniques allow determination of local and seasonal geospatial movements of birds. Techniques allowing identification of individuals after marking include numbered leg bands, neck collars for marking geese and swans (Craighead and Stockstad 1956; Samuel et al. 2001; Zadegan 2004; Williams et al. 2008), nasal markers for ducks (Sugden and Poston 1968; Lokemoen and Sharp 1985; Brook and Clark 2002), and patagial and leg tags (Cummings 1987; Claridge 1990; Linz et al. 1992; Carver et al. 1999; Houston and Bloom 2005). Neck collars and patagial tags can be read without recapture, while numbered leg bands and leg tags typically require recapture. Techniques that allow identification of marked birds out of a group include coloured leg bands and flags (Balham and Elder 1953; Hill 1992; Watt 2001; Regehr and Rodway 2003) and temporary dyes (Wadkins 1948; Moseley and Mueller 1975; Wendeln et al. 1996; Donehower and Bird 2005). Through single or multiple bird captures, these marking methods enable the investigation of movements of marked individuals.

DayGlo $^{1}$ (DayGlo Colour Corp., Cleveland, Ohio) fluorescent particle formulation (A/AX Pigments) (hereafter referred to as 'marker') is available worldwide for marking wild birds (Jaeger et al. 1986; Knittle et al. 1996). It is a liquid formulation that dries and adheres to the feather surface with some (material) lodging in the feather barbules (Otis et al. 1986). Most reported uses of this marker have been aerial applications with a fixed-wing airplane for large aggregates of birds. Recent advancements enable small flocks to be marked using a ground spray system (P. T. Oesterle, National Wildlife Research Center, Fort Collins, CO, USA, unpubl. data), and a tower spray system adapted from Bullard (1990).

Knittle et al. (1987) marked 10.6 million red-winged blackbirds (Agelaius phoeniceus) in Missouri and South Dakota, USA, with marker. Linz et al. (1991) and Homan et al. (2004) used a different marker formulation to mark 300000 and 370000 blackbirds in North Dakota and South Dakota, USA, respectively. After marking, birds in these studies were systematically shot and collected along migrational pathways or in breeding areas and examined for marker. Collections enabled researchers to determine turnover rates at summer roosts, and spring migration patterns to breeding sites. This technique is also useful to ascertain local movement patterns. For example, 70 European starlings (Sturnus vulgaris) were marked using a remotely activated ground spray device (P. T. Oesterle, National Wildlife Research Center, Fort Collins, CO, USA, unpubl. data). Lethal collection and examination of birds at surrounding feedlots allowed researchers in this study to study the potential for disease transfer between feed lots.

This technique is one of the few practical means of marking large numbers of birds for monitoring movement. Despite its use in the field setting, only minor anecdotal and empirical data have been collected to evaluate longevity of DayGlo fluorescent particle marker on birds. Information on the longevity of the marker is crucial for determining detection capabilities. Bruggers

${ }^{1}$ Use of brand names does not imply USDA endorsement. 
and Bortoli (1979) documented the longevity of a variety of formulations on the wings of red-billed quelea (Quelea quelea) and other weaver birds (Ploceus spp.) for up to 115 days. Jaeger et al. (1986) recovered marked wings 67-100 days after marking. Knittle and Johns (1986) described a 29\% pigment loss after 42 days. In contrast to the adhesive used in these earlier studies (No. 2 diesel fuel), we used Carboset 514H (Lubrizol Advanced Materials, Inc., Cleveland, Ohio, USA) as an adhesive in our formulation due to environmental concerns of spraying diesel fuel in wetlands. We are not aware of any published data describing the retention of the current DayGlo Fluorescent particle marker formulation on feathers (Johns et al. 1989). Thus, our aim was to monitor the longevity of the DayGlo Fluorescent particle marker on red-winged blackbirds under simulated field conditions. Additional data on longevity of marker were obtained through collections of blackbirds from a field marker study in south-eastern Missouri, USA.

\section{Materials and methods}

\section{Flight pen study}

We conducted this study at the Outdoor Animal Research Facility of the United States Department of Agriculture (USDA), National Wildlife Research Center (NWRC), in Fort Collins, Colorado, USA. All birds had been field-caught several months before the experiment, and were maintained in $4.9 \times 2.4 \times 2.4 \mathrm{~m}$ cages within an open-sided building exposed to ambient environmental conditions. After marking, we placed birds into a 0.07 -ha flight pen with a pole-supported net roof $\left(1^{\prime \prime} \times 1^{\prime \prime} \mathrm{mesh}\right)$ $7.6 \mathrm{~m}$ high at the centre and $2.4 \mathrm{~m}$ high at the sides. We provided birds free access to water, grit, and maintenance feed ( 2 millet : 1 milo: 1 safflower: 1 sunflower). Two wooden shelters $(1.8 \mathrm{~m} \times 2.4 \mathrm{~m})$, three $1.5-\mathrm{m}$ potted ponderosa pine (Pinus ponderosa) trees and white cedar (Thuja occidentalis) branches were available for roosting. We followed animal care criteria outlined by the animal welfare act and the NWRC institutional animal care and use committee (USA Federal Permit No. MB019065-14 and Colorado State Permit No. 04TR060).

We used the DayGlo Fluorescent particle marker formulation described by Linz et al. (1991), Knittle et al. (1996), and Homan et al. (2004). A $950 \mathrm{~mL}$ solution of this formulation was mixed within 30 min of application. On 1 December 2004, 52 male redwinged blackbirds were banded with individually numbered leg bands and then held by the wrists and evenly sprayed on both dorsal and ventral surfaces from $\sim 50 \mathrm{~cm}$ with a 1 -L adjustable spray bottle. This application of marker is similar to well marked portions of birds from field application with fixed-wing airplane, and the tower spray method. We placed sprayed birds in an indoor pen $(2.1 \mathrm{~m} \times 2.4 \mathrm{~m} \times 2.1 \mathrm{~m})$ lined with a soft mesh net for holding while all 52 blackbirds were marked. The marker material dried in less than $1 \mathrm{~min}$, and all 52 birds were then transported to the flight pen. Birds in the flight pen were exposed to direct sunlight, ambient temperatures, rain, and snow, and potential wear factors such as bathing, dusting and abrasion from vegetation and netting.

We used a modified crow-trap (Gadd 1996) to recapture birds at least monthly from December 2004 through August 2005, when birds began to moult. We tried to capture more than $75 \%$ of the birds during each assessment. Birds were placed in a burlap sack for transport to minimise human-caused abrasion of the marker. We used a model B-100A Black-Ray long-wave $(360 \mathrm{~nm})$ ultraviolet light in a darkened observation room to detect the marker and determine marker retention. Although marker can be visible to the naked eye, a darkened room was used to minimise error in judging the marker retention. We categorised four general body regions of the birds using the major feather tracts: head region or capital tract; body region or spinal ventral, femoral and crural tracts; tail region or caudal tract; and wing region or humeral and alar tracts. On each region we used the following categories to rate the area covered by the marker: (0) no marks visible; (1) 1-5 marks visible; (2) $>5$ marks visible but less than $50 \%$ of the region covered; (3) $>50 \%$ of body region covered, but less than full coverage of region; and (4) marks on entire region. A mark indicated a visible spot of marker material. After the initial spray each bird was determined via visual observation to be a Category 4 for each body region.

We documented the time until marks were lost from the four regions of each bird based on recaptures by individual band numbers through the beginning of moult in August 2005. The time in day(s) until the marks of each bird reached the respective categories (i.e. Category 3, 2, or 1) was analysed non-parametrically using Kaplan-Meier (Kaplan and Meier 1958) survival analyses (up to a total of 254 days). Wilcoxon comparisons of survival curves were used to compare regions of each bird for their longevity within marking categories (Kalbfleish and Prentice 1980). Analyses were conducted using SAS PROC LIFETEST (SAS Institute 2004). Birds dying during the study were considered censored at the time of the event and were eliminated from further analyses. The analyses enabled the use of mark survival times through the censoring event.

\section{Field study}

Three mixed flocks of blackbirds (red-winged blackbirds, brown-headed cowbirds (Molothrus ater), and common grackles (Quiscalus quiscula)) estimated at 700000,750000 , and 2.2 million were each aerially marked once between 29 September and 2 October 2005 (post-moult) in southeastern Missouri. We collected birds from October 2005 through June 2006 at varying intervals in the area surrounding the spray sites (Table 1). We used a model B-100A Black-Ray long-wave $(360 \mathrm{~nm})$ ultraviolet light in available darkened observation areas (i.e. warehouse space) to detect birds with marker.

\section{Results}

\section{Flight pen study}

We recaptured red-winged blackbirds and assessed DayGlo fluorescent particle marks 11 times between 1 December 2004 and 10 August 2005, or an average of every 23 days (s.e. \pm 8.6 days). We recaptured $27-86 \%$ of the birds during each assessment period (Fig. 1). We observed 21 bird mortalities during the study. Mortalities were generally associated with recapture and handling ( $0-2$ per recapture event). Five mortalities were definitively attributed to hawk or owl 
Table 1. Summary data for mixed flocks of blackbirds collected between October 2005 and November 2006 in south-eastern Missouri, USA. Species included are red-winged blackbirds (Agelaius phoeniceus), brown-headed cowbirds (Molothrus ater) and common grackles (Quiscalus quiscula)

\begin{tabular}{lccc}
\hline $\begin{array}{l}\text { Days after } \\
\text { marking }\end{array}$ & $\begin{array}{c}\text { No. of birds } \\
\text { collected }\end{array}$ & $\begin{array}{c}\text { No. of birds } \\
\text { marked }\end{array}$ & $\begin{array}{c}\text { Percentage of } \\
\text { birds marked }\end{array}$ \\
\hline $1-20$ & 594 & 524 & $88.2^{\mathrm{A}}$ \\
$21-40$ & 261 & 36 & 13.80 \\
$41-60$ & 306 & 22 & 7.20 \\
$61-80$ & 737 & 53 & 7.20 \\
$81-100$ & 135 & 9 & 6.70 \\
$101-120$ & 99 & 6 & 6.10 \\
$121-140$ & 33 & 1 & 3.00 \\
$141-160$ & 105 & 4 & 3.80 \\
$161-180$ & 0 & 0 & 0.00 \\
$181-200$ & 0 & 0 & 0.00 \\
$201-220$ & 211 & 81 & 38.40 \\
$221-240$ & 110 & 18 & 16.40 \\
$241-260$ & 8 & 1 & 12.50 \\
$260+$ & 27 & 3 & 11.10 \\
Total & 2626 & 758 & 28.90 \\
\hline
\end{tabular}

${ }^{\mathrm{A}}$ Birds collected on day immediately following aerial spray.

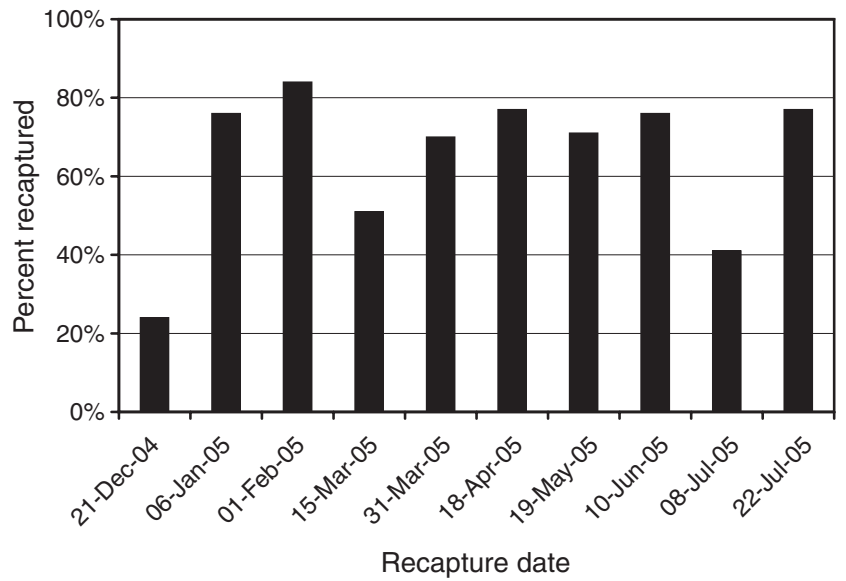

Fig. 1. Proportion of the study population ( $n=52$ red-winged blackbirds (Agelaius phoeniceus)) recaptured for visual inspection of the DayGlo fluorescent particle marks standardised to include mortality occurring between observations from December 2004 through August 2005 at the National Wildlife Research Center (NWRC) Outdoor Animal Research Facility flight pen.

predation (i.e. decapitation, talon marks observed). Predators were able to capture birds through the flight pen netting.

Median longevities for body region classification as Marking Category 4 on the body, head, tail, and wing regions were 19, 84, 77 and 154 days, respectively. Those for Marking Category 3 or better on the body, head, tail, and wing regions were 130,133, 154 and 243 days, respectively. Strong differences were observed between different body regions for longevity within Category 4 (Fig. 2) and also Category 3 (Fig. 3) (Wilcoxon comparison of Kaplan-Meier survival curves: $\chi^{2}=144.47$, d.f. $=1, P<0.0001$; $\chi^{2}=70.97$, d.f. $=1, P<0.0001$, respectively).

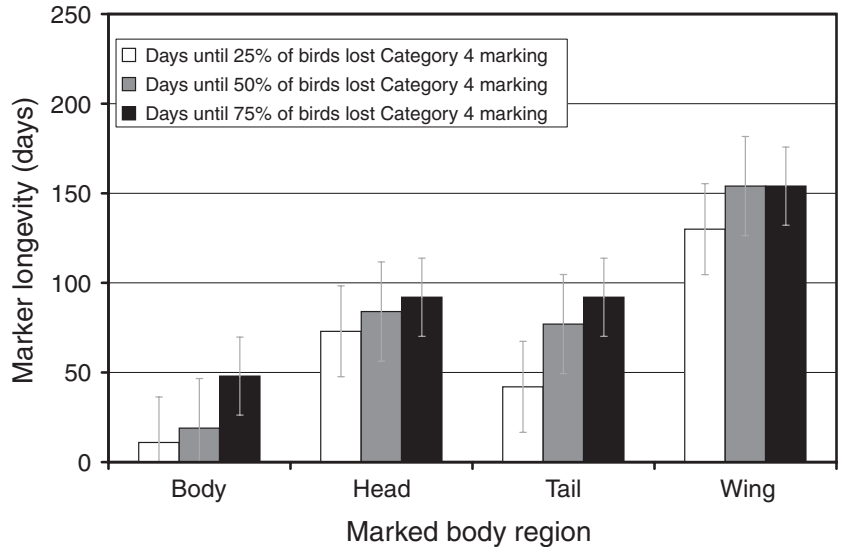

Fig. 2. Longevity of Category 4 (i.e. marks on entire region) DayGlo fluorescent particle marker among marked red-winged blackbirds (Agelaius phoeniceus). Error bars represent standard error.

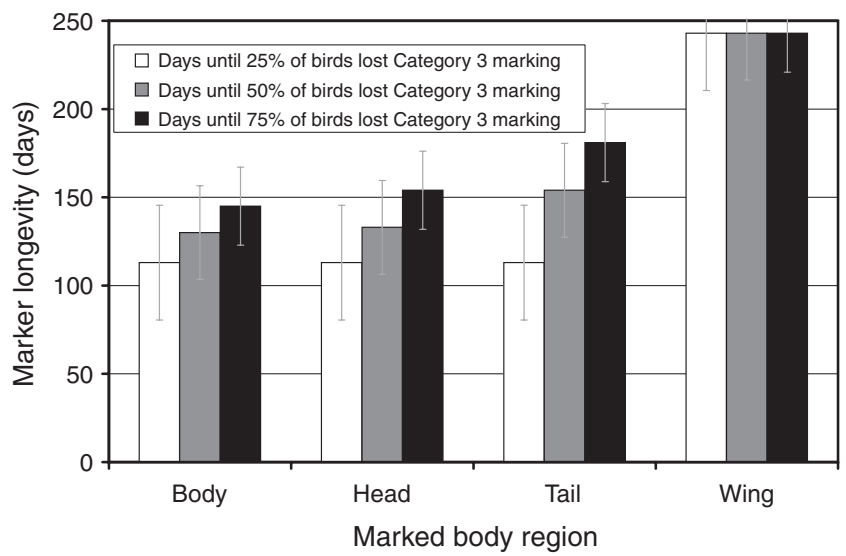

Fig. 3. Longevity of Category 3 (i.e. $>50 \%$ of body region covered, but less than full coverage of region) DayGlo fluorescent particle marker among $25 \%, 50 \%$, and $75 \%$ of marked red-winged blackbirds (Agelaius phoeniceus). Error bars represent standard error.

\section{Field study}

Birds were shot during 27 collections between October 2005 and June 2006 or an average of every 11 days in the area surrounding the spray sites. In total, 2626 birds were collected. We had no means of knowing how many of the 2626 had been sprayed, but 758 of the collected birds were found to have marks. Three of the 758 birds with marks were collected on 21 June 2006, or 263 days after marking, indicating the potential for long-term mark retention during the period between moults (Table 1).

\section{Discussion}

All test birds remaining at the conclusion of the pen study retained at least some DayGlo fluorescent particle marker through 254 days following our simulated aerial application of the marker. Moult precluded further longevity testing. All birds still had regions with Category 2 markings (i.e. more than 5 marks visible but less than $50 \%$ total region covered) at the conclusion of the study. The level of initial spray of each bird in 
the flight pen study is supported by the results of the field study, which found one bird with fluorescent particle marks at 259 days after marking and three birds with fluorescent particle marks at 263 days after marking.

The DayGlo fluorescent particle marks on the wings (both dorsal and ventral sides) lasted 243 days as Category 3, more than 89 days longer than those on the head, tail, or body. The feathers of the wing have pennaceous barbules that generally are larger and have more highly developed barbicels than those of body contour feathers (Stettenheim 1972), and thus are able to retain the DayGlo fluorescent particle marks longer. Although tail feathers are of the same type as wing feathers and so have the same highly developed barbicels, they are used for balance and therefore are exposed to greater abrasion due to perching, and thus do not retain DayGlo fluorescent particle marks as long as do wing feathers.

Precautions were taken during the multiple recaptures to minimise marker wear due to handling to ensure that marker wear was due to bird behaviour not human handling. Blackbirds were transported in burlap bags instead of hard plastic transport boxes. Even though these precautions were taken, flecks of the marker were still present in the burlap bags after each assessment. During the study several birds became accustomed to the modified crow trap and entered and exited the trap before we could examine them for DayGlo fluorescent particle marks. These birds, although captured fewer times overall, showed marker longevity similar to that of birds captured during each recapture, indicating that the recapture method did not cause undue degradation of the marker.

Toxicity testing of the DayGlo particle formulation at concentrations ranging from 25 to $6000 \mathrm{ppm}$ on four species of fish showed minimal mortality to two species (rainbow trout (Salmo gardneri) and bluegills (Lepomis promelas)) at concentrations of $6000 \mathrm{ppm}$. During actual marker-spray operations, water concentrations typically do not exceed an average of $5 \mathrm{ppm}$ (Bills and Knittle 1986). In a study to simulate contamination of upland habitat, egg production, fertility, bodyweight and food consumption were not negatively impacted in common quail (Coturnix coturnix) that ingested feed treated with $6.12 \mathrm{~mL} \mathrm{lb}^{-1}$ of DayGlo particle formulation (Scott et al. 1984). Thus, the levels that we applied in our study would not be a cause of mortality to our study birds.

Application of DayGlo fluorescent particle marker formulation by spraying is a widely used and very valuable technique for marking birds. Despite the high-tech options available, this remains one of the few practical means to mark large numbers of birds for monitoring movement. Probably, this is the only economically feasible method for such applications. Despite the method's wide use, this is the first designed study to evaluate marker longevity. The current cost of this formulation is approximately US\$4.00 $\mathrm{L}^{-1}$. This technique of mark and collection would be cost effective at many scales (for example we previously marked 2 million blackbirds with only $379 \mathrm{~L}$ of the formulation: Cummings et al. unpubl. data) and with many species of birds that congregate either in local small flocks or in larger aggregates including starlings, blackbirds, sparrows, gulls and shorebirds.

\section{Acknowledgements}

We thank A. Taylor, D. T. King, G. M. Linz., N. M. Roberts, M. E. Tobin, and S. J. Werner as well as several anonymous reviewers for their thoughtful comments on earlier versions of this manuscript. We also thank R. W. Byrd for assistance with marking and collecting birds and the staff of NWRC's Animal Care unit for care of the birds throughout the study. The capture, care, and use of animals associated with this study were approved by NWRC's Institutional Animal Care and Use Committee (NWRC Study Protocol QA1235).

\section{References}

Balham, R. W., and Elder, W. H. (1953). Colored leg bands for waterfowl. Journal of Wildlife Management 17, 446-449. doi: 10.2307/3797049

Bills, T. D., and Knittle, C. E. 1986. Toxicity of DayGlo ${ }^{\circledR}$ fluorescent pigment material to four species of fish. Unpublished Bird Damage Research Report No. 359, Denver Wildlife Research Center, USDA, Denver, CO.

Brook, R. W., and Clark, R. G. (2002). Retention and effects of nasal markers and subcutaneously implanted radio transmitters on breeding female lesser scaup. Journal of Field Ornithology 73, 206-212.

Bruggers, R. L., and Bortoli, L. (1979). Laboratory trials using fluorescent dyes and paints as marking agents for quelea studies. In 'Vertebrate Pest Control and Management Materials. ASTM STP 680'. (Ed. J. R. Beck.) pp. 231-236. (American Society for Testing and Materials.)

Bullard, R. W. (1990). PA-14 (Tergitol 15-S-9)-Registration No. 56228-13Directions for Use. MRID PA14/171-3. Unpublished Report, Denver Wildlife Research Center, Denver, CO.

Carver, A. V., Brennan, L. A., and Burger, L. W. Jr. (1999). Passive integrated transponders and patagial tag markers for northern bobwhite chicks. Journal of Wildlife Management 63, 162-166. doi: 10.2307/3802497

Claridge, G. F. (1990). Methods for attaching patagial tags and a description of a new method. Corella 14, 91-93.

Craighead, J. J., and Stockstad, D. S. (1956). A colored neckband for marking birds. Journal of Wildlife Management 20, 331-332. doi: 10.2307/ 3796979

Cummings, J. L. (1987). Nylon fasteners for attaching leg and wing tags to blackbirds. Journal of Field Ornithology 58, 265-269.

Donehower, C. E., and Bird, D. M. (2005). A method for color-marking birds at resting sites. Journal of Field Ornithology 76, 204-207.

Gadd, P. Jr. (1996). Use of the modified Australian crow trap for the control of depredating birds in Sonoma County. In 'Proceedings of the 17th Vertebrate Pest Conference'. (Eds R. M. Timm and A. C. Crabb.) pp. 103-107. (University of California: Davis, CA.)

Hill, G. E. (1992). An inexpensive source of colored leg bands. Journal of Field Ornithology 63, 408-410.

Homan, H. J., Linz, G. M., Engeman, R. M., and Penry, L. B. (2004). Spring dispersal patterns of red-winged blackbirds, Agelaius phoeniceus, staging in eastern South Dakota. Canadian Field Naturalist 118, 201-209.

Houston, C. S., and Bloom, P. H. (2005). Turkey vulture marking history: the switch from leg bands to patagial tags. North American Bird Bander 30, 59-64.

Jaeger, M. M., Bruggers, R. L., Johns, B. E., and Erickson, W. A. (1986). Evidence of itinerant breeding of the red-billed quelea (Quelea quelea) in the Ethiopian Rift Valley. The Ibis 128, 469-482. doi: 10.1111/j.1474919X.1986.tb02699.x

Johns, B. E., Bruggers, R. L., and Jaeger, M. M. (1989). Mass-marking quelea with fluorescent pigment particles. In 'Quelea quelea, Africa's Bird Pest'. (Eds R. L. Bruggers and C. C. H. Elliott.) pp. 50-60. (Oxford University Press: Oxford.)

Kalbfleish, J. D., and Prentice, R. L. (1980). 'The Statistical Analysis of Failure Time Data.' (John Wiley and Sons: New York.)

Kaplan, E. L., and Meier, P. (1958). Nonparametric estimation from incomplete observations. Journal of the American Statistical Association 53, 457-481. doi: 10.2307/2281868 
Knittle, C. E., and Johns, B. E. (1986). Field-spray comparison of two particle-marker formations used to mass-mark red-winged blackbirds. Unpublished Bird Damage Research Report No. 359, Denver Wildlife Research Center, USDA, Denver, CO.

Knittle, C. E., Linz, G. M., Johns, B. E., Cummings, J. L., Davis, J. E. Jr, and Jaeger, M. M. (1987). Dispersal of male red-winged blackbirds from two spring roosts in central North America. Journal of Field Ornithology 58, 490-498.

Knittle, C. E., Linz, G. M., Cummings, J. L., Davis, J. E. Jr, Johns, B. E., and Besser, J. F. (1996). Spring migration patterns of male red-winged blackbirds (Agelaius phoeniceus) from two migratory roosts in South Dakota and Minnesota. American Midland Naturalist 136, 134-142. doi: $10.2307 / 2426638$

Linz, G. M., Knittle, C. E., Cummings, J. L., Davis, J. E. Jr, Otis, D. L., and Bergman, D. L. (1991). Using aerial marking for assessing population dynamics of late summer roosting red-winged blackbirds. The Prairie Naturalist 23, 117-126.

Linz, G. M., Knittle, C. E., and Johnson, R. E. (1992). Home-range of breeding common ravens in coastal southern California. The Southwestern Naturalist 37, 199-202. doi: 10.2307/3671670

Lokemoen, J. T., and Sharp, D. E. (1985). Assessment of nasal marker materials and designs used on dabbling ducks. Wildlife Society Bulletin 13, 53-56.

Moseley, L. J., and Mueller, H. C. (1975). A device for color-marking nesting birds. Bird-banding 46, 341-342.

Otis, D. L., Knittle, C. E., and Linz, G. M. (1986). A method for estimating turnover in spring blackbird roosts. Journal of Wildlife Management 50, 567-571. doi: 10.2307/3800964

Regehr, H. M., and Rodway, M. S. (2003). Evaluation of nasal discs and colored leg bands as markers for harlequin ducks. Journal of Field Ornithology 74, 129-135.

Samuel, M. D., Goldberg, D. R., Smith, A. E., Baranyuk, V. V., and Cooch, E. G. (2001). Neckband retention for lesser snow geese in the western Arctic. Journal of Wildlife Management 65, 797-807. doi: $10.2307 / 3803029$
SAS Institute (2004). 'SAS/STAT User's Guide. Vol. 3.' (SAS Institute: Carey, NC.)

Scott, E. J., Schafer, E. C., and Schafer, E. W. Jr (1984). Evaluation of the effects of DayGlo ${ }^{\circledR}$ pigments and carriers used for mass-marking wild birds on body weight, food consumption, egg production and fertility of coturnix quail. Unpublished Bird Damage Research Report No. 324, Denver Wildlife Research Center, USDA, Denver, CO.

Stettenheim, P. (1972). The integument of birds. In 'Avian Biology. Vol. II'. (Eds D. S. Farner and J. R. King.) pp. 9-13. (Academic Press Incorporated: New York.)

Sugden, L. G., and Poston, H. J. (1968). A nasal marker for ducks. Journal of Wildlife Management 32, 984-986. doi: 10.2307/3799582

Wadkins, L. A. (1948). Dyeing birds for identification. Journal of Wildlife Management 12, 388-391. doi: 10.2307/3795927

Watt, D. J. (2001). Recapture rate and breeding frequencies of American goldfinches wearing different colored leg bands. Journal of Field Ornithology 72, 236-243.

Wendeln, H., Nagel, R., and Becker, P. H. (1996). A technique to spray dyes on birds. Journal of Field Ornithology 67, 442-446.

Williams, C. K., Samuel, M. D., Baranyuk, V. V., Cooch, E. G., and Kraege, D. (2008). Winter fidelity and apparent survival of lesser snow goose populations in the Pacific Flyway. Journal of Wildlife Management 72, 159-167. doi: 10.2193/2005-748

Zadegan, S. S. (2004). A short report on flamingo (Pheonicopterus rubber) ringing at Lake Uromiyeh (Iran) and recoveries in Turkey. The Ring 26, 93-94.

Manuscript received 7 February 2009, accepted 3 March 2009 